\title{
SLURRY SURFACING MIXES ON THE BASIS OF BITUMEN MODIFIED WITH PHENOL-CRESOL-FORMALDEHYDE RESIN
}

\author{
Yuriy Demchuk ${ }^{1}{ }^{凶}$, Volodymyr Gunka ${ }^{1}$, Serhiy Pyshyev ${ }^{1}$, Iurii Sidun ${ }^{2}$, \\ Yurii Hrynchuk ${ }^{1}$, Justyna Kucinska-Lipka ${ }^{3}$, Michael Bratychak ${ }^{1}$
}

https://doi.org/10.23939/chcht14.02.251

\begin{abstract}
Slow-breaking monophase cationic bitumen emulsions have been produced on the basis of bitumen modified with phenol-cresol-formaldehyde resin (PhCR-F). Bitumen emulsions were used as a binder for thin-layer coatings with slurry surfacing mixes (SSM). Physical and technical parameters of modified and unmodified emulsions were determined and analyzed. The optimal compositions of SSM were selected according to the breaking criterion. The values of SSM wet track abrasion were determined. It was found that the addition of PhCR-F allows to improve the adhesion properties of the thin-layer coatings.
\end{abstract}

Keywords: bitumen emulsion, emulsifier, slurry surfacing mixes, thin-layer coating, modified bitumen, adhesion, phenol-cresol-formaldehyde resin.

\section{Introduction}

Bitumen, as the main organic binder for road technology, is used in three states: hot (at the temperatures above $413 \mathrm{~K}$ ), diluted (using solvents) and bituminous emulsions (BE). The latest state is particularly effective due to the increase in productivity and quality of work, as well as cleanliness and improved working conditions.

Bitumen emulsions have a number of advantages over traditional "hot" technologies:

- the binder is distributed as thinner uniform films, which allows to reduce bitumen consumption by $20-40 \%$ and eliminates the possibility of layers "sweating";

- saving up to $40 \%$ of fuel due to the refusal of stone materials heating;

\footnotetext{
${ }^{1}$ Institute of Chemistry and Chemical Technology

Lviv Polytechnic National University,

12, Bandera St., 79013 Lviv, Ukraine

${ }^{2}$ Institute of Building and Environmental Engineering,

Lviv Polytechnic National University,

12, Bandera St., 79013 Lviv, Ukraine

${ }^{3}$ Department of Polymer Technology,

Gdansk University of Technology,

11/12, G. Narutowicza St., 80-233 Gdansk, Poland

$\bowtie$ yuriy_demchuk@ukr.net

(C) Demchuk Y., Gunka V., Pyshyev S, Sidun Iu., Hrynchuk Y., Kucinska-Lipka J., Bratychak M., 2020
}

- the higher adhesive ability of BE promotes the creation of strong and durable road structures with stone materials, which makes it possible to work in damp and cool (up to $278 \mathrm{~K}$ ) weather;

- reduction of harmful emissions into the atmosphere and improvement of working conditions for the personal.

But there are also some drawbacks of using BE: the possibility of emulsion washing-out during prolonged rains; the final formation of coatings under the influence of motion is slower than that when using the "hot" method; the coating formation requires particularly careful care [1-9].

$\mathrm{BE}$ are produced by dispersing (crushing) bitumen into particles of $1-10 \mu \mathrm{m}$ in the emulsifier aqueous solution with the addition of acid or alkali. BE may include polymeric, adhesive and other additives. As a result, two types of modified bitumen emulsion are distinguished; the first type is manufactured on the basis of modified bitumen (monophase emulsion) and the second one is modified after manufacture (two-phase emulsion). The first type is the most often used.

In spray applications the emulsion is used for surface dressing (chip seal), fog seal, scrub seal, graded aggregate seal, tack coat, prime coat, penetration macadam and dust control. In mix applications it is used for SSM (slurry seal, microsurfacing), cape seal, opengraded cold mix, dense-graded cold mix, soil stabilization, pre-coated chips, stockpile mix and RAP [6]. SSM technology is used to prepare thin-layer coatings (TLC).

SSM is obtained via mixing macadam (with the particles size of less than $15 \mathrm{~mm}$ ) or undersized crushedstone, bitumen emulsion (BE), water, mineral filler and regulator of emulsion lability at the ambient temperature not below $298 \mathrm{~K}$. The main aim for the production of TLC with SSM is to extend the service life of the existing coatings due to cracks and small pot-holes pouring, considerable increase of roughness and adhesive properties, improvement of coating evenness, prevention of crack formation, protection from water saturation and rebuilding of worn or preservation of the existing coating upper layer [7].

When producing TLC with SSM, poor cohesion and adhesion properties of the mixture are observed. Poor cohesion results in long curing time of the mixture, tardy 
hardening of TLC and late commencement of service. Poor adhesion properties cause weak adhesion of the newly formed layer to the base on which it is attached; poor adhesive bonding between the bituminous binder and the rock material of the mixture and insufficient adhesion between the stone materials that are already enveloped by the binder (that is what leads to a low cohesive strength of the mixture itself).

So, the problem of low cohesive strength is the adhesion of the used bituminous binder. Therefore, to get high-quality TLC with SSM, it is necessary to use a modified binder. Phenol-cresol-formaldehyde resins (PhCR-F), derived from the phenolic fraction of coal tar and synthesized by the polycondensation method of "raw" phenols with formaldehyde is among modifiers. The addition of PhCR-F in the amount of $0.5-1.0 \mathrm{wt} \%$ relative to bitumen significantly increases bitumen adhesive properties and provides a complete, irreversible and waterproof bond between the binder and the stone material [10-13].

Thus, the purpose of this work was to establish the possibility of obtaining bitumen emulsions and TLC with SSM from PhCR-F modified bitumen.

\section{Experimental}

\subsection{Initial Materials}

To obtain the modified bitumen, we used the oxidized bitumen BND 60/90 produced by PJSC "Transnational financial and industrial oil company Ukrtatnafta" (Kremenchuk, Ukraine). The characteristics of pure bitumen are given in Table 1.

Phenol-cresol-formaldehyde resin (PhCR-F) was obtained via polycondensation of "raw" phenols produced using the phenolic fraction of coal tar and formaldehyde under the conditions given in [10-13].

The mixing process was carried out as follows. The required quantity of bitumen was weighed and heated to $463 \mathrm{~K}$. The modification conditions were [10-13]: PhCR-F content $1 \mathrm{wt} \%$, mixing duration $1 \mathrm{~h}$, and temperature $463 \mathrm{~K}$. The characteristics of modified bitumen are given in Table 1.

According to the recipe, bitumen emulsions contained Redicote E-11 (Nouryon, Sweden) emulsifier (Table 2).

Table 1

Characteristics of pure and PhCR-F modified bitumen

\begin{tabular}{|l|c|c|c|}
\hline \multicolumn{1}{|c|}{ Index } & Pure bitumen & PhCR-F modified bitumen & Standards \\
\hline Penetration at $298 \mathrm{~K}, \mathrm{~m} \cdot 10^{-4}$ & 70 & 68 & EN 1426:2000 [14] \\
\hline Softening point R\&B, $\mathrm{K}$ & 319 & 321 & EN 1427:2007 [15] \\
\hline Ductility at 298 K, $\mathrm{m} \cdot 10^{-2}$ & 63 & 46 & EN 13589:2008 [16] \\
\hline Adhesion to glass, $\%$ & 33 & 87 & {$[17]$} \\
\hline Adhesion to crushed stone, points & 3 & 5 & {$[18]$} \\
\hline Fraass breaking point, K & 255 & 255 & EN 12593 [19] \\
\hline Penetration index & -1.5 & -0.9 & EN 12591 [20] \\
\hline
\end{tabular}

Table 2

Characteristics of Redicote E-11 emulsifier for slow-breaking cationic BE

\begin{tabular}{|l|c|}
\hline \multicolumn{1}{|c|}{ Appearance } & Liquid at $298 \mathrm{~K}$ \\
\hline $\mathrm{pH}$ & $6-9(5 \%$ in $50 / 502$-propanol $/$ water $)$ \\
\hline Active content of solid phase, \% & $48-53$ \\
\hline Density at 293 K, $\mathrm{kg} / \mathrm{m}^{3}$ & 900 \\
\hline Flash point, $\mathrm{K}$ & 291 \\
\hline Pour point, $\mathrm{K}$ & 253 \\
\hline Viscosity at 293 K, $\mathrm{mPa} \cdot \mathrm{s}$ & 50 \\
\hline Solubility in water & Soluble \\
\hline
\end{tabular}

Table 3

The estimated grading 0-10 for the type 2 mix ISSA

\begin{tabular}{|c|c|c|}
\hline \multirow{2}{*}{\begin{tabular}{c} 
Orifices $\begin{array}{c}\text { for round-shaped } \\
\text { sieves, } \mathrm{mm}\end{array}$ \\
\cline { 2 - 3 }
\end{tabular}} & \multicolumn{2}{|c|}{ Average grading 0-10 for the type 2 mix ISSA, wt \% } \\
\hline 0 & 30 & Complete passing through sieves \\
\hline 0.5 & 40 & 0 \\
\hline 2 & 20 & 30 \\
\hline 5 & 10 & 70 \\
\hline 10 & 0 & 90 \\
\hline
\end{tabular}


To obtain SSM we used: $0-10 \mathrm{~mm}$ fraction of granite scree (JSC "Klesivsky Mine of Rock Products", Klesiv, Ukraine); Portland cement of type 400 (JSC "Mykolaivcement", Mykolaiv, Ukraine); regulating additive $-10 \%$ aqueous solution of Redicote E-11 (Nouryon, Netherlands).

The SSM grading was designed for the type 2 with the coarse filler maximum particles size of $10 \mathrm{~mm}$ [21]. In order to avoid the influence of grading peculiarities on the indices of cohesion strength build-up rate, the SSM design was performed on the basis of exactly the same narrow fractions. The selected SSM mix grading refers to type 2 (Table 3 ) and corresponds to the limit values according to ISSA technical bulletin [21].

\subsection{Experimental Procedure}

\subsubsection{Production of bitumen emulsions}

The bitumen emulsions were prepared using a colloidal mill. The process was as follows:

- preparation of the "water phase";

- preparation of the "bitumen phase";

- mixing of two phases by laboratory bitumenemulsion unit.

In general, modified emulsions are obtained according to the same scheme as unmodified ones, except for the modifier introduction. In accordance with manufacturing technology the modified emulsions are divided into monophase and two-phase emulsions. Monophase modified $\mathrm{BE}$ are prepared on the basis of modified bitumen, i.e. the modifier (modifying agent) has already been introduced into bitumen. In most cases, the high viscosity of the modified bitumen demands higher dispersion temperature compared with that for the unmodified emulsions. As a result, the emulsion temperature at the colloidal mill outlet may be above $373 \mathrm{~K}$. It is necessary to modify the traditional equipment to provide the pressure of $0.15-0.2 \mathrm{MPa}$ and to use a cooling system (usually a heat exchanger) at the outlet of the mixer. When producing two-phase modified emulsions, the modifier is added as an emulsion system (latex). Latex may be introduced by various ways: by dispersing in the aqueous phase; by injecting directly into the dispersed (bitumen) phase; by direct injection into a colloid mill or by addition to the resulting bitumen emulsion.

In our case, the PhCR-F modifier was pre-injected into bitumen and the monophase bitumen emulsions were prepared at the temperature typical of unmodified emulsions (below $373 \mathrm{~K}$ ).

$\mathrm{BE}$ were produced according to the scheme shown in Fig. 1.

To calculate the amount of components necessary to prepare bitumen emulsion a computer program, attached to the laboratory bitumen-emulsion installation was used. Physico-technical indices of BE were determined in accordance with [21].

\section{Aqueos phase - 38 wt\%}

BE1 and BE2 -water: Redicote E11 (98.9:1.1 w/w)

BE2a - water: Redicote E11 (99.1:0.9 w/w)

$\mathrm{HCl}$ was added till $\mathrm{pH}=2.5$ (emulsifier activation)
Bitumen phase - $62 \mathrm{wt} \%$

BE1 - BND 60/90 bitumen (100 wt \%)

BE2 and BE2a - BND 60/90 bitumen modified with PhCR-F (99:1 w/w)

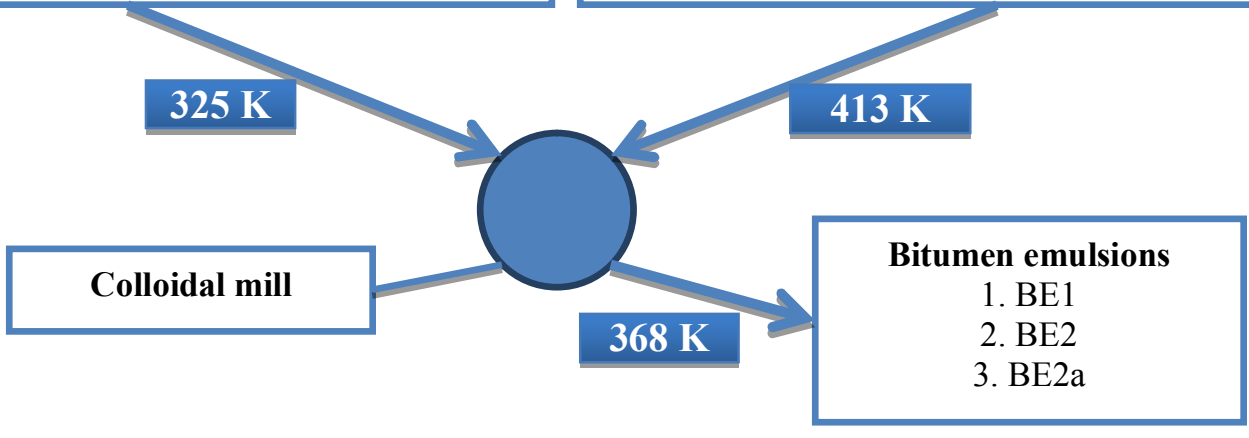

Fig. 1. The scheme of BE production 


\subsubsection{Production of TLC with SSM}

SSM was prepared and tested according to ISSA requirements [21-23] and EN standard [24] at $298 \mathrm{~K}$ and air relative humidity of $77 \%$. SSM composition was designed to achieve necessary time of its break (time from all components mixing till the moment the mixture loses its mobility and possibility of further mixing). This criterion determines the time during which the mixture should be prepared and layered. The general procedure for SSM break is as follows:

- mixing of mineral components, water, regulating additive and bitumen emulsion in the enamel vessel;

- manual mixing of the obtained mixture by means of spatula in the tilted enamel vessel to evaluate the mixture mobility during all experiment time;

- fixing of mixture break. The content of all components is considered as an optimum one, when the mixture break continues not less than $120 \mathrm{~s}$.

\subsubsection{Wet Track Abrasion of SSM Systems}

This test method measures the wearing qualities of SSM systems under wet abrasion conditions.

The procedure is as follows. The stone material is sifted through a sieve and at least $800 \mathrm{~g}$ and poured into a mixing cup. A pre-calculated amount of mineral filler (cement) is added and the mixture is stirred for $1 \mathrm{~min}$ with a spatula. After adding the water (to obtain the cone spread in the range from 2.5 to $3.0 \mathrm{~cm}$ ) the mixture is stirred again for $1 \mathrm{~min}$. A certain amount of emulsion is poured and stirred for 30-45 s. Immediately after mixing with the binder, the sample is poured into the mould, previously placed on a pitch paper and centered. The excess of the sample is removed by a rounded-shape trowel and the surface is levelled. After the emulsion break the mould is removed, and the sample on the plate is placed in an oven for $15 \mathrm{~h}$. The drying temperature is $333 \pm 2 \mathrm{~K}$. The dried sample is removed from the oven and cooled to room temperature. After weighing $\left(m_{0}, \mathrm{~g}\right)$, the sample is placed in a water bath at $298 \pm 1 \mathrm{~K}$ for 60 $75 \mathrm{~min}$. Then the sample is put in the mixer pan and clamped. The pan is filled with water (temperature $298 \pm 1 \mathrm{~K}$ ) to the entire height of the sample. The thickness of the water layer over the sample should be in the range of $5.5-6.5 \mathrm{~mm}$. A rubber hose is mounted on the wear head shaft of the mechanical mixer. The mixer platform is lifted in such a way that the head rests freely on the material surface. The platform position is fixed with a lock. The mixer is switched on, causing the head to rotate in a circle and erase the surface of the material. The test time is $300-405 \mathrm{~s}$, depending on the planetary mixer brand. After cyclic erasure, the sample is removed from the pan, washed with water, placed again in the oven (temperature $333 \pm 2 \mathrm{~K}$ ) and dried till the constant weight. The dried sample is cooled at room temperature and weighed $\left(m_{1}, \mathrm{~g}\right)$.

The loss of material during wet abrasive wear is calculated according to Eq. (1) [25]:

$$
W T A=\left(m_{0}-m_{1}\right) \cdot k
$$

where WTA is the loss of material weight during wet wear test, $\mathrm{g} / \mathrm{m}^{2} ; m_{0}$ and $m_{1}$ is the weight of the sample before and after wear, respectively; $k$ is a conversion factor, which depends on the mixer brand and varies in the range from 29 to 35 . In our case for Hobart C-100 mixer the value of $k$ was 32.9 .

\section{Results and Discussion}

\subsection{BE Production}

The monophase bitumen emulsions BE1, BE2, BE2a were produced using pure bitumen (BE1) and PhCR-F modified bitumen (BE2 and BE2a, Table 4). The recommended amount of the Redicote E-11 emulsifier for slow-breaking bitumen emulsions was reduced for BE2a emulsion. Among the quick-breaking, mid-breaking and slow-breaking emulsions, the latter ones were chosen because this is the type of emulsion recommended for the SSM production.

Table 5 shows the physical and technical characteristics of monophase modified emulsions in comparison with the basic sample BE1. According to [26] BE1 corresponds to the ECS- 60 brand, and the modified $\mathrm{BE}$ (BE2 and BE2a) correspond to the ECSM-60 brand. To compare with other samples, BE2a is characterized by lower values of breaking index and stability during storage. The reason is the less amount of emulsifier in it. So, to obtain a high-quality modified bitumen emulsion, it is not recommended to reduce the amount of emulsifier, because physico-technical indices for such emulsion are on the brink of the requirements for ECSM-60 [26].

Table 4

Composition of bitumen emulsions

\begin{tabular}{|c|c|c|c|c|}
\hline \multirow{2}{*}{$\mathrm{BE}$} & \multicolumn{4}{|c|}{ Components of emulsions, $\% \mathrm{w} / \mathrm{w}$} \\
\hline & Bitumen & Redicote E-11 & Hydrochloric acid in aqueous phase till $\mathrm{pH}$ & Water \\
\hline BE1 & \multirow{3}{*}{62.0} & 1.1 & \multirow{3}{*}{2.5} & \multirow{3}{*}{100} \\
\hline BE2 & & 1.1 & & \\
\hline $\mathrm{BE} 2 \mathrm{a}$ & & 0.9 & & \\
\hline
\end{tabular}


Physico-technical indices of bitumen emulsions

\begin{tabular}{|c|c|c|c|c|c|c|}
\hline \multirow{2}{*}{\multicolumn{2}{|c|}{ Index }} & \multicolumn{2}{|c|}{ Requirements according to [26] } & \multicolumn{3}{|c|}{ Bitumen emulsions } \\
\hline & & ECS-60 & ECSM-60 & BE1 & BE2 & $\overline{\mathrm{BE} 2 \mathrm{a}}$ \\
\hline \multicolumn{2}{|l|}{ Appearance } & \multicolumn{2}{|c|}{ Homogeneous dark-brown liquid } & \multicolumn{3}{|c|}{\begin{tabular}{|l} 
Fits the requirements \\
\end{tabular}} \\
\hline \multicolumn{2}{|l|}{ Hydrogen ions concentration, $\mathrm{pH}$} & \multicolumn{2}{|c|}{$1.5-6.5$} & 3.12 & 3.9 & 4.0 \\
\hline \multicolumn{2}{|l|}{ Homogeneity (sieve No.014 residue), $\%$, at most } & 0.25 & 0.3 & 0.06 & 0.08 & 0.1 \\
\hline \multicolumn{2}{|l|}{ Content of residual binding agent, $\%$} & \multicolumn{2}{|c|}{$58-62$} & 61.08 & 61.2 & 61.25 \\
\hline \multicolumn{2}{|c|}{ Assumed viscosity at $298 \mathrm{~K}$ (apparatus with hole diameter of $4 \mathrm{~mm}$ ), $\mathrm{s}$} & \multicolumn{2}{|c|}{$5-25$} & 10.0 & 11.2 & 11.8 \\
\hline \multicolumn{2}{|c|}{$\begin{array}{l}\text { Stability during storage: sieve No.014 residue, } \% \\
\text { - after } 7 \text { days } \\
\text { - after } 30 \text { days }\end{array}$} & $\begin{array}{l}\leq 0.3 \\
\leq 0.4\end{array}$ & $\begin{array}{l}\leq 0.4 \\
\leq 0.5\end{array}$ & $\begin{array}{l}0.12 \\
0.21 \\
\end{array}$ & $\begin{array}{l}0.38 \\
0.42\end{array}$ & $\begin{array}{l}0.40 \\
0.50\end{array}$ \\
\hline \multicolumn{2}{|l|}{ Adhesion of residual binding agent to macadam, points } & \multicolumn{2}{|c|}{$\geq 5.0$} & 5.0 & 5.0 & 5.0 \\
\hline \multirow{2}{*}{ Miscibility with mixtures of grained composition } & porous & \multirow{2}{*}{\multicolumn{2}{|c|}{$\frac{t}{+}$}} & + & + & + \\
\hline & dense & & & + & + & + \\
\hline \multicolumn{2}{|l|}{ Breaking index, \% } & \multicolumn{2}{|c|}{$170-230$} & 210.25 & 200 & 173 \\
\hline
\end{tabular}

The technological advantage of PhCR-F modified bitumen is the production temperature which is usual for unmodified emulsions production $(373 \mathrm{~K})$. The modification does not provide bitumen with elasticity and increases its viscosity.

\subsection{Determination of SSM Optimum Composition and Wet Track Abrasion (WTA)}

The optimum compositions of SSM represented in Table 6, were designed according to the breaking criterion (break should occur no earlier than after $120 \mathrm{~s}$ ). The compositions are similar except for the content of breaking regulator, the function of which is to regulate the mixing time of the ingredients. In other words, this component allows the mixture to stay mobile for a certain period of time. The emulsion BE2 requires some larger amount of regulator compared with BE1, probably due to the better adhesion properties. BE2a requires twice more regulator than $\mathrm{BE} 1$, because the amount of emulsifier in it is $0.9 \mathrm{wt} \%$ against $1.1 \mathrm{wt} \%$.

In accordance with Eq. (1) we determined the loss of material during wet abrasive wear, because this particular value indicates the SSM durability, which depends directly on the adhesion properties of the mixture.

WTA of SSM allows to determine the weight loss of water-saturated material from the mixture under mechanical abrasion by a rubber surface for $5 \mathrm{~min}$. This test simulates the wear of a wet thin-layer coating, namely its mass loss during vehicle movement. This study also makes it possible to evaluate the adhesion of bituminous binder to stone material and the minimum amount of bitumen required in the mixture.

Table 6

Optimum compositions of SSM according to the breaking criterion

\begin{tabular}{|c|c|c|c|c|c|c|}
\hline \multirow{2}{*}{ BE } & \multicolumn{5}{|c|}{ Components content, g } & \multirow{2}{*}{ Breaking time, s } \\
\cline { 2 - 7 } & Granite scree & Portland cement & Water & Regulating additive & Bitumen emulsion & \\
\hline BE1 & 100 & 1.0 & 10 & 1.0 & 14 & 127 \\
\hline BE2 & 100 & 1.0 & 10 & 1.2 & 14 & 125 \\
\hline BE2a & 100 & 1.00 & 10 & 2.0 & 14 & 124 \\
\hline
\end{tabular}

Table 7

WTA test for SSM

\begin{tabular}{|c|c|c|}
\hline BE & WTA, $\mathrm{g} / \mathrm{m}^{2}$ & Specification (ISSA TB 100 [23]) \\
\hline BE1 & 542 & $\begin{array}{c}\text { One-hour soak } \\
\leq 538 \mathrm{~g} / \mathrm{m}^{2}\end{array}$ \\
\hline BE2 & 59 & \\
\hline BE2a & 75 & \\
\hline
\end{tabular}


WTA test results for SSM are represented in Table 7. One can see that the WTA value is much higher for BE1 (pure bitumen). The addition of PhCR-F has a positive effect on WTA value and allows to reduce it to the standard value [23]. When comparing the WTA values for BE2 and BE2a we observe the lower value for the composition, which contains more emulsifier (BE2). This fact can be explained by a better adhesion of residual bituminous binder formed after the emulsion breaking.

PhCR-F modified bitumen in the SSM composition provides high adhesive properties of the wear layer and hence, the durability of thin-layer coatings.

\section{Conclusions}

The possibility of cationic road bitumen emulsions based on bitumen modified with phenol-cresolformaldehyde resins (PhCR-F) has been proved. The resulting emulsions have improved technological properties, namely adhesion. The technological advantage of PhCR-F modified bitumen is the standard temperature of bitumen phase preparation, which is impossible with the use of traditional SBS polymers.

Due to the high adhesion of modified bitumen the slurry surfacing mixes (SSM) on its basis provide excellent adhesive properties of the wear layer and hence, the durability of thin-layer coatings. The introduction of PhCR-F in SSM allows significant reduction of weight loss during a wet abrasive wear and its adjustment to standard value in accordance with ISSA TB 100.

\section{Acknowledgments}

The work was carried out under financial support of the PROM Programme - International Scholarship exchange of $\mathrm{PhD}$ students and academic staff - no PPI/PRO/2019/1/00009/U001 of the Polish National Agency for Academic Exchange.

\section{References}

[1] Fang X., Garcia-Hernandez A., Lura P.: RILEM Techn. Lett., 2016, 10, 116. https://doi.org/10.21809/rilemtechlett.2016.23 [2] Al Nageim H., Al-Busaltan S., Atherton W. et al.: Construct. Build. Mater., 2012, 36, 743.

https://doi.org/10.1016/j.conbuildmat.2012.06.032

[3] Al-Hdabi A., Al Nageim H., Seton L.: Construct. Build. Mater., 2014, 69, 362. https://doi.org/10.1016/j.conbuildmat.2014.07.081

[4] Boucard L., Schmitt V., Farcas F. et al.: Road Mater. Pavement Design, 2015, 16, 330.

https://doi.org/10.1080/14680629.2015.1030910

[5] Thanaya I., Zoorob S., Forth J.: Proc. Inst. Civil Eng. Transport, 2009, 162, 47. https://doi.org/10.1680/tran.2009.162.1.47

[6] Sidun Iu., Solodkyy S., Vollis O.: J. Civil Eng., Environ., Architect., 2018, XXXV, 83. http://doi.prz.edu.pl/pl/pdf/biis/1063

[7] Pyshyev S., Grytsenko Y., Solodkyy S. et al.: Chem. Chem.

Technol., 2015, 9, 359. https://doi.org/10.23939/chcht09.03.359

[8] Sidun Iu., Solodkyy S., Shved M, et al.: Chem. Chem. Technol.,

2019, 13, 489. https://doi.org/10.23939/chcht13.04.489
[9] Sidun Iu., Vollis O., Solodkyy S. et al.: [in:] Blikharskyy Z., Koszelnik P., Mesaros P. (Eds.), Lecture Notes in Civil Engineering. CEE 2019: Proceedings of CEE 2019. Springer 2019, 47, 420. https://doi.org/10.1007/978-3-030-27011-7 53

[10] Demchuk Y., Sidun Iu., Gunka V. et al.: Chem. Chem. Technol., 2018, 12, 456. https://doi.org/10.23939/chcht12.04.456

[11] Pyshyev S., Demchuk Yu., Gunka V. et al.: Chem. Chem. Technol., 2019, 13, 212. https://doi.org/10.23939/chcht13.02.212

[12] Gunka V., Demchuk Yu., Pyshyev S. et al: Pet. Coal, 2018, 60, 1199.

[13] Pyshyev S.,Demchuk Y., Gunka V.: Uglekhim. Zh., 2019, 4, 27. https://doi.org/10.31081/1681-309X-2019-0-4-27-33

[14] EN 1426:2000. European Standard. Bitumen and bituminous binders. Methods of tests for petroleum and its products.

Determination of needle penetration.

[15] EN 1427:2007. European Standard. Bitumen and bituminous binders. Determination of the softening point. Ring and Ball method. [16] EN 13589:2008. European Standard. Bitumen and bituminous binders. Determination of the tensile properties of modified bitumen by the force ductility method.

[17] http://online.budstandart.com/ua/catalog/doc-page?id_doc=6392

[18] http://online.budstandart.com/ua/catalog/doc-

page.html?id_doc $=4917$

[19] EN 12593. European Standard. Bitumen and bituminous binders. Determination of the Fraas breaking point.

[20] EN 12591. European Standard. Bitumen and bituminous binders - Specifications for paving grade bitumens.

[21] ISSA A143. Recommended Performance Guideline For Micro Surfacing, 2010.

[22] ISSA Technical Bulletin 113. Test Method for Determining Mix Time for SSM Systems, 2017.

[23] ISSA Technical Bulletin 100. Laboratory Test Method for Wet Track Abrasion of SSM Systems, 2018.

[24] EN 12274-4. European Standard.Slurry surfacing. Test methods. Determination of cohesion of the mix.

[25] http://online.budstandart.com/ua/catalog/docpage.html?id_doc $=60842$

[26] http://online.budstandart.com/ua/catalog/docpage?id_doc $=54091$

Received: August 12, 2019 / Revised: August 18, 2019 / Accepted: January 20, 2020

\section{ЛИТІ ЕМУЛЬСІЙНІ МІНЕРАЛЬНІ СУМІШІ НА ОСНОВI БIТУМIB, МОДИФІКОВАНИХ ФЕНОЛО-КРЕЗОЛО- ФОРМАЛЬДЕГІДНОЮ СМОЛОЮ}

\begin{abstract}
Анотація. 3 бітумів, модифікованих феноло-крезолоформальдегідною смолою (ФіКС-Ф), виготовлені дорожні повільнорозкладні монофазні катіонні бітумні емульсї для застосування як зв'язучого для тонкошарових покриттів з литих емульсійних мінеральних сумішей (ЛЕМС). Встановлені та проаналізовані фізико-технічні показники модифікованих $i$ немодифікованих емульсій. Підібрані оптимальні склади ЛЕМС за критерісм розкладу на основі виготовлених бітумних емульсій. Встановлені показники вологого абразивного зношування ЛЕМС та встановлено, щчо додавання ФіКС-Ф покращує адгезійні властивості тонкошарового покриття.
\end{abstract}

Ключові слова: бітумні емульсї, емульгатор, литі емульсійні мінеральні суміші, тонкошарове покриття, модифікований бітум, адгезія, феноло-крезоло-формальдегідна смола. 